\title{
MALIGNE BOLESTI U PEDIJATRIJSKOM UZRASTU
}

\author{
Jelena Lazić ${ }^{1,2}$
}

\author{
${ }^{1}$ Univerzitetska dečja klinika, Beograd, Srbija \\ ${ }^{2}$ Medicinski fakultet Univerziteta u Beogradu
}

Maligniteti dečjeg uzrasta spadaju u retke bolesti, čineći svega $1 \%$ od ukupnog broja obolelih od raka. Prema najnovijim podacima, u svetu je u 2012. godini kod 3.450.000 ljudi dijagnostikovana neka maligna bolest [1]. Smatra se da incidenca kancera raste, ali se povećan broj novoobolele dece i odraslih svakako može pripisati i preciznijoj dijagnostici. S druge strane, mortalitet se značajno smanjuje, zahvaljujući ranoj detekciji, preciznijoj subklasifikaciji bolesti i savremenim modalitetima lečenja.

\section{Epidemiologija i prognoza malignih bolesti kod dece}

Aktuelni podaci iz literature ukazuju na incidencu raka od oko 150/1.000.000 dece godišnje. U Evropi na godišnjem nivou oboli oko 15.000 , dok se procenjuje da u svetu, u istom vremenskom okviru, taj broj iznosi oko 200.000 dece i adolescenata [2]. S obzirom na to da u Srbiji ne postoji nacionalni registar za maligne bolesti, podaci se dobijaju iz bolničkih protokola i na osnovu učešća u internacionalnim studijama, gde postoji obaveza prijavljivanja pacijenata. Broj novoobolele dece od raka godišnje u našoj zemlji iznosi oko 300 .

Najučestaliji malignitet dečje dobi su akutne leukemije (32\%), među kojima je najčešća akutna limfoblastna leukemija (ALL), koja čini $3 / 4$ svih obolelih od akutnih leukemija. Slede tumori centralnog nervnog sistema (CNS), limfomi i potom različiti solidni tumori [3]. Učestalost malignih bolesti kod dece je predstavljena u tabeli 1.

U odnosu na uzrast u momentu dijagnoze, različita je zastupljenost određenih malignih bolesti. U ranom odojačkom i predškolskom uzrastu dominiraju tumori embrionalnog porekla (neuroblastom, nefroblastom, retinoblastom i hepatoblastom), dok se $\mathrm{u}$ adolescenciji češće javljaju limfomi, tumori centralnog nervnog sistema i tumori germinativnih ćelija. Distribucija maligniteta je različita i u odnosu na pol: kod dečaka se češće javljaju ALL, ne-Hočkinski limfom (NHL) i koštani tumori, dok kod devojčica prednjače tumori tiroidee [3].

Danas se, zahvaljujući preciznoj dijagnostici i individualizaciji terapije prema strogo definisanoj stratifikaciji rizika, postiže ukupno izlečenje u dece sa malignim bolestima od oko $85 \%$ u visoko razvijenim zemljama, i oko $70 \%$ u zemljama u razvoju [4]. U našoj sredini je,
Tabela 1. Distribucija učestalosti malignih bolesti u pedijatriji.

\begin{tabular}{|c|c|c|}
\hline Akutne leukemije & $\begin{array}{l}\text { Akutna limfoblastna leukemija, akutna mijeloidna } \\
\text { leukemija, hronična granulocitna leukemija, juvenilna } \\
\text { mijelo-monocitna leukemija }\end{array}$ & $32 \%$ \\
\hline Tumori CNS-a & $\begin{array}{l}\text { Neuroepitelni tumori (gliom), embrionalni tumori } \\
\text { (meduloblastom), primitivni neuroektodermalni } \\
\text { tumori, ependimomi, kraniofaringeom }\end{array}$ & $20 \%$ \\
\hline Limfomi & $\begin{array}{l}\text { Ne-Hočkinski limfom, Hočkinov limfom, anaplastični } \\
\text { krupnoćelijski limfom }\end{array}$ & $11 \%$ \\
\hline Neuroblastom & & $7 \%$ \\
\hline Sarkomi mekih tkiva & $\begin{array}{l}\text { Rabdomiosarkom, sinovijalni sarkom, fibrosarkom, } \\
\text { Ewing }\end{array}$ & $7 \%$ \\
\hline Tumori bubrega & $\begin{array}{l}\text { Wilms (nefroblastom), rabdoidni tumor, svetloćelijski } \\
\text { karcinom bubrega, kongenitalni mezoblastični } \\
\text { nefrom, karcinom ćelija bubrežnog parenhima }\end{array}$ & $6 \%$ \\
\hline Tumori kosti & Osteosarkom, Ewing & $4 \%$ \\
\hline Endokrini tumori & $\begin{array}{l}\text { Tumori hipofize i hipotalamusa, tumori tireoidee i } \\
\text { paratireoidee, tumori adrenalnog korteksa, medule i } \\
\text { adrenergičkih ganglija, gastropankreatični tumori }\end{array}$ & $4 \%$ \\
\hline Retinoblastom & & $3 \%$ \\
\hline $\begin{array}{c}\text { Tumori } \\
\text { germinativnih ćelija }\end{array}$ & $\begin{array}{l}\text { Ovarijalni i testikularni tumori, ekstragonadalni } \\
\text { tumori (teratomi) }\end{array}$ & $2 \%$ \\
\hline Tumori jetre & $\begin{array}{l}\text { Hepatoblastom, hepatocelularni karcinom, bilijarni } \\
\text { adenom, hemangioendoteliom, fibrolamelarni } \\
\text { karcinom, angiosarkom, angiomiolipom }\end{array}$ & $1 \%$ \\
\hline Drugi retki tumori & & $3 \%$ \\
\hline
\end{tabular}

kao i u svetu, zabeležen porast stope preživljavanja. Rezultati studije kod dece sa ALL, sprovedene u periodu od 1995-2002. godine, su ukazali na preživljavanje od 70\% [5], a u narednom studijskom periodu, od 2002-2009. godine, zahvaljujući učešču u internacionalnim randomizovanim studijama, taj procenat se popeo na $82 \%$ [6]. U odnosu na vrstu maligne bolesti, u tabeli 2 je prikazan procenat preživljavanja u razvijenim zemljama [4].

U Evropi trenutno živi i radi oko 400.000 ljudi koji su u detinjstvu izlečeni od različitih malignih bolesti [7]. Međutim, bez obzira na ohrabrujuće rezultate, rak je i dalje vodeći uzrok smrtnosti u pedijatrijskoj populaciji nakon prve godine života.

\section{Patogeneza dečjih malignih bolesti}

Uprkos brojnim pokušajima da se u potpunosti razjasni kancerogeneza, i dalje je kod većine malignih 
Tabela 2. Procenat preživljavanja u odnosu na različite maligne bolesti $\mathrm{u}$ dece.

\begin{tabular}{|l|c|}
\hline Retinoblastom & $99 \%$ \\
\hline Hočkinov limfom & $97 \%$ \\
\hline Akutna limfoblastna leukemija & $90 \%$ \\
\hline Nefroblastom & $90 \%$ \\
\hline Ne-Hočkinov limfom & $85 \%$ \\
\hline Neuroblastom & $79 \%$ \\
\hline Tumori CNS-a & $75 \%$ \\
\hline Ewing-ov sarkom & $72 \%$ \\
\hline Osteosarkom & $71 \%$ \\
\hline Akutna mijeloidna leukemija & $64 \%$ \\
\hline Rabdomiosarkom & $64 \%$ \\
\hline
\end{tabular}

bolesti etiologija nedovoljno jasna. Da bi se razumeo proces nastanka malignog oboljenja, potrebno je sagledati prirodu i ponašanje maligne ćelije.

U organizmu se svakodnevno dešava nebrojeno mnogo procesa na ćelijskom nivou, gde su moguće greške, koje u najvećem broju ispravlja gen za popravku DNK (DNA repair gen). Međutim, greške koje nisu ispravljene mogu da dovedu do maligne alteracije. Smatra se da jedna greška nije dovoljna, što je 1953. godine kao hipotezu postavio Carl Nording, a potom je 1971. godine razvio Alfred Knudson. Knudsonova "two-hit“ hipoteza (hipoteza dva udarca), na primeru retinoblastoma, obrazlaže da se prvi udarac dešava u germinativnoj ćeliji roditelja, drugi u germinativnoj ćeliji bolesnika, što rezultuje stvaranjem tumora [8]. Teorija multiplih mutacija je i danas aktuelna - kancerogeneza zavisi od aktivacije protoonkogena (gena koji stimulišu proliferaciju) i deaktivacije tumor supresornih gena (gena koji je kontrolišu). Tumor supresorni geni kodiraju proteine koji suprimiraju rast ćelija na više načina: šalju signal ćeliji da uspori i zaustavi deobu, utiču na popravku oštećenih ćelija i kontrolišu apoptozu. Rekombinacioni sistem, odgovoran za normalne somatske rearanžmane, povećava frekvencu aberantnih rekombinacionih događaja, što može dovesti do mutacije u genima uključenim u regulaciju tri važna ćelijska procesa: proliferacije, diferencijacije i/ ili apoptoze, sa posledičnom malignom transformacijom ćelije [9]. Mutacije u bilo kom momentu, bilo koje funkcije ćelije, mogu dovesti do kancerogeneze. Najnovija istraživanja ukazuju na izrazitu heterogenost mutacija kod raka, zbog čega se danas smatra da rak predstavlja „100 različitih bolesti“. Ispitivanja upućuju da frekvenca mutacija varira više od 1000 puta između najniže i najviše među različitim malignitetima, ali i unutar nekoliko vrsti tumora, što daje odgovor na pitanje zašto svi pacijenti ne reaguju pozitivno na primenjenu terapiju [10].
Specifičnost pedijatrijske hematologije i onkologije je u povezanosti sa određenim kongenitalnim sindromima, koji mogu biti hereditarnog karaktera ili dovesti do veće učestalosti kancera unutar jedne porodice. Brojne su anomalije i sindromi koji koreliraju sa malignitetima dečjeg uzrasta i predstavljeni su na tabeli 3. Takođe, veća incidenca različitih vrsta raka je zabeležena kod dece sa urođenim hromozomskim anomalijama, kao što su numeričke mutacije. Jedan od primera je veća incidenca ALL i akutne mijeloidne leukemije (AML) kod dece sa Daunovim sindromom (Down Sy) [11].

Tabela 3. Udruženost pedijatrijskih maligniteta i kongenitalnih anomalija i sindroma.

\begin{tabular}{|c|c|}
\hline Neurofibromatoza (tip I) & $\begin{array}{l}\text { Tumori CNS, neuroblastom, rabdomiosarkom, } \\
\text { maligni tumor ovojnice perifernih nerava }\end{array}$ \\
\hline $\begin{array}{c}\text { Li-Fraumeni: mutacija TP53, } \\
\text { porodična predispozicija za } \\
\text { ranu pojavu raka }\end{array}$ & $\begin{array}{l}\text { Osteosarkom, rabdomiosarkom, tumori CNS, } \\
\text { akutna limfoblastna i mijeloidna leukemija, } \\
\text { adrenokortikalni karcinom }\end{array}$ \\
\hline Rubinstein-Taybi & $\begin{array}{l}\text { Akutna limfoblastna i mijeloidna leukemija, } \\
\text { tumori CNS, rabdomiosarkom }\end{array}$ \\
\hline Beckwith-Wiedemann & Wilms, rabdomiosarkom, hepatoblastom \\
\hline Prader-Willi & Akutna mijeloidna leukemija \\
\hline Denys-Drash & Wilms \\
\hline WAGR & Wilms \\
\hline Goldenhar & Akutna limfoblastna i mijeloidna leukemija \\
\hline $\begin{array}{l}\text { Anomalije urogenitalnog trakta, } \\
\text { CNS, GIT, KVS }\end{array}$ & Različiti maligniteti \\
\hline $\begin{array}{c}\text { Familijarna polipoza creva } \\
\text { (FAP) }\end{array}$ & $\begin{array}{l}\text { Kolorektalni karcinom, tumori CNS, } \\
\text { hepatoblastom }\end{array}$ \\
\hline
\end{tabular}

I strukturne hromozomske aberacije, kao mutageni događaji specifičnog tipa, mogu inicirati maligni proces ako se dogode u hromozomskom regionu u kojem je lociran neki od protoonkogena. Jedan od primera izmenjene interakcije je stvaranje fuzionih gena i njihovo učešće u leukemogenezi. Danas su detektovani mnogi genetski rearanžmani za koje je poznato da koreliraju sa određenim malignitetima, od kojih deo ima značajnu ulogu i kao objekat ciljane terapije. Prva detektovana translokacija sa jasnim značajem u leukemogenezi je $\mathrm{t}(9 ; 22)(\mathrm{q} 34 ; \mathrm{q} 11)$, odnosno Filadelfija $(\mathrm{Ph})$ hromozom [12]. Prvi lek koji je pokazao uspešnost ciljane genetske terapije, kontruisan je upravo prema $\mathrm{Ph}$ hromozomu. Radi se o inhibitoru tirozin kinaze (Imatinib mesylate), zahvaljujući kom su postignuti odlični rezultati u lečenju hronične mijeloidne leukemije (CML) kod odraslih i ALL u dece [13]. Dok je Ph hromozom stečen genetski događaj, postoji i onaj koji nastaje intrauterino, kao što je najčešće detektovan genetski rearanžman kod dece 
sa ALL, gde se javlja u 25\% bolesnika. To je kriptična translokacija $\mathrm{t}(12 ; 21)$, odnosno fuzioni gen TEL/AML1 (sinonim ETV6/RUNX1), za koji je dokazan da je fetalnog porekla, jer je u monozigotnih blizanaca nađena ista, jedinstvena, nekonstitucionalna fuzija TEL/AML1 gena [14].

Iz prethodno navedenog, jasno je da potreba da se razjasni etiopatogeneza malignih bolesti nema samo naučni, već i praktični značaj. Mogućnost prevencije i usmerene terapije ka poznatom uzroku daleko je veća, nego u domenu pretpostavki. Sa tim ciljem je oformljena ENCCA (European Network for Cancer Research in Children and Adolescents), koja se bavi istraživanjem etiopatogeneze i novih terapijskih modaliteta u pedijatrijskoj hematologiji i onkologiji [15].

\section{Razlike između zdrave i maligne ćelije}

Normalna ćelija prestaje da se razmnožava kada je u organizmu prisutno dovoljno ćelija da obavi zadatu funkciju, za razliku od maligne, koja nastavlja da se besmisleno reprodukuje. Svaki gen nosi nacrt kodova za različite proteine: kada se dogodi mutacija u genu, koji kodira proteine odgovorne za faktor rasta (onkogen), ćelija nastavi da se bezgranično razmnožava. U tom rapidnom procesu, ćelije raka se reprodukuju pre nego što imaju šansu za maturacijom (sazrevanjem). Što je maligna ćelija na nižem stupnju sazrevanja, to je njen maligni potencijal veći.

Ćelije raka nemaju interakciju sa drugim ćelijama putem različitih signala, kao što zdrave ćelije komuniciraju. Mutacije u signalnim putevima dovode do brzog širenja pogrešne informacije ka zdravim ćelijama. Zdrave ćelije podležu apoptozi (programiranoj ćelijskoj smrti), za razliku od malignih. Ukoliko gen koji popravlja DNK nije u stanju da ispravi grešku, protein p53 (koji spada u tumor supresorne gene) šalje signal zdravoj ćeliji da podlegne apoptozi, što se ne dešava kod maligne ćelije. Ukoliko postoji mutacija u genu p53, stare ćelije i one sa greškom nastavljaju da se razmnožavaju, što dovodi do multiplikacije grešaka i maligne alteracije. Dužina telomera utiče na životni vek: skraćuje se svaki put tokom deobe zdrave ćelije. Maligne ćelije, zahvaljujući enzimu telomerazi, obnavljaju dužinu telomera, zbog čega ne podležu apoptozi i nastavljaju deobu [16].

Kada se posmatraju pod mikroskopom, maligne ćelije imaju neuobičajen oblik, sa većim i tamnijim jedrom. Boja i veličina jedra su drugačije jer sadrže neumerenu količinu izmenjene DNK, a često i izmenjen broj i organizaciju hromozoma. Razlika između zdrave i maligne ćelije prikazana je na slici $\mathbf{1}$. Genomska nestabilnost maligne ćelije ogleda se u tome da mutacije mogu da dovedu do kancerogeneze, a mogu i da imaju potpuno odsustvo funkcije u malignoj ćeliji. Zdrave ćelije ispunjavaju svoju zadatu funkciju, a maligne su izmenjene ne samo u obliku, već i u funkcionalnosti. Npr. funkcija zdravih leukocita je da pomažu u odbrani od infekcije. Kod leukemija, iako su leukociti često prisutni u daleko većem broju nego u normalnim okolnostima, zahvaljujući malignoj alteraciji, ne samo da ne učestvuju u odbrani organizma, već ga dodatno ugrožavaju, jer nezrelost i izmenjena funkcija ćelija bele loze dovodi do povećanog rizika od infekcija.

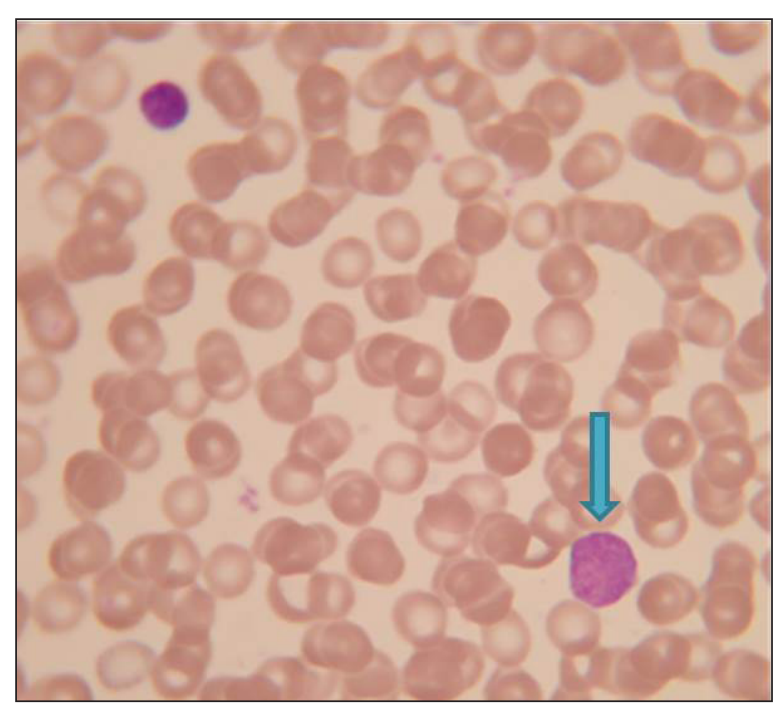

Slika 1. Zdrav i maligno izmenjen (strelica) limfocit-limfoblast.

Zdrave ćelije se snabdevaju energijom tokom Krebsovog ciklusa, preko ATP i pomoću glikolize, u prisustvu kiseonika. Maligne ćelije stvaraju svoju energiju nezavisno od kiseonika, odnosno u njegovom odsustvu [17]. Sa takvim osobinama, maligne ćelije su u stanju da prevare ćelije imunskog sistema. Limfociti prepoznaju i pomažu u uklanjanju oštećenih ćelija u normalnim okolnostima, međutim maligne ćelije sekretuju supstance koje inaktivišu ćelije imunskog sistema, tako da nisu u stanju da ih prepoznaju i odstrane.

Zdrave ćelije sekretuju supstance (adhezioni molekuli) koje ih drže u grupi, za razliku od malignih koje plutaju ili do okolnih struktura ili preko krvotoka i limfotoka u udaljene delove tela, što dovodi do metastatskog procesa. Reč kancer je nastala od latinske reči $k r a b a$, da bi na slikovit način, kao ponašanje kraba u životinjskom svetu, opisala invaziju na proksimalne ili distalne strukture. 


\section{Klinička slika dece obolele od raka}

Simptomi i znaci malignih bolesti na svojoj prezentaciji u dečjem uzrastu vrlo često su nespecifični, polimorfni, mogu trajati od par dana do par meseci. Pogotovo je teško na osnovu kliničke slike posumnjati na malignu bolest, u odojačkom uzrastu ili ranom detinjstvu, kada deca ne mogu da verbalizuju svoje tegobe.

Jedan od najčešćih simptoma u pedijatriji je bol, a bol je uglavnom prvi simptom bolesti kod većine solidnih tumora. Deca se često žale na različite vrste bolova, a u mlađem uzrastu ne postoji varijetet opisa tegoba, tako da pod terminom bol prolaze i razne druge neprijatne senzacije. Međutim, na ponavljani bol, koje dete uporno lokalizuje na jednom mestu, bez jasno vidljivog otoka ili promene boje kože svakako treba obratiti pažnju. Bolovi u kostima mogu da predstavljaju „bol rasta“, koji je fiziološki, ali takođe mogu da budu prvi simptom bolesti, npr. kod akutnih leukemija ili infiltracije koštane srži nemalignim ćelijama hematopoeze. Takođe, lako nastale frakture kostiju, kod deteta koje prethodno nije bilo sklono povređivanju, ukazuju na malignitet.

Jedan od prvih znakova maligne bolesti je gubitak telesne težine, čemu prethodi gubitak apetita. U dečjem uzrastu se beleži veliki prirast u telesnoj masi i dužini/visini, tako da se svaki gubitak ili stagnacija shvataju ozbiljno. Naravno, potrebno je objektivno sagledati gubitak, jer roditelji nekada imaju utisak da dete gubi na težini kada ima najveći longitudinalni rast, ili su utiska da je apetit oslabljen, kada nemaju uvid u obroke deteta van kuće. Precizno merenje telesne visine i težine i računanje gubitka prema percentilima za uzrast i pol su jedini ispravan način da se objektivizuju anamnestički podaci.

Pored bola, jedan od najčešćih stanja u pedijatriji je povišena telesna temperatura. Deca provode vreme u kolektivima (obdaništa, škole, igraonice), gde su podložna različitim infekcijama, koje su često praćene febrilnošću. Međutim, febrilnost bez jasnog znaka infekcije, intermitentnog toka, sa skokovima temperature koji nisu septični (od $37,5-38,5^{\circ} \mathrm{C}$ ), najčešće u večernjim časovima, bude sumnju na malignitet. Takođe, kao i kod telesne mase i visine, potrebno je objektivizovati febrilnost, preciznim merenjem adekvatnim toplomerima prema uzrastu deteta.

Pojava noćnog preznojavanja je takođe znak koji može biti fiziološki, jer roditelji često pretopljavaju svoju decu, pogotovo u našoj sredini, ali u isto vreme predstavlja jedan od simptoma malignih bolesti. Navedene tegobe, na koje je neophodno obratiti pažnju tokom uzimanja anamneze, spadaju u „B simptome“: febrilnost bez jasnog fokusa infekcije, gubitak telesne težine, malaksalost i noćno preznojavanje.

Deca se, zbog izrazite fizičke aktivnosti, često povređuju u detinjstvu. Međutim, neuobičajena pojava hemoragijskog sindroma u koži i vidljivim sluzokožama (hematomi, petehije, ekhimoze), koji ne odgovara stepenu udarca, može da bude prvi znak raka, najčešće akutnih leukemija. Hemoragijski sindrom na koži je prikazan na slikama 2 i 3. Takođe, akutno ponavljano krvarenje (gingivoreja, epistaksa, hematohezija, hematurija), bez znaka erozije sluzokože i u odsustvu drugih stanja koja mogu biti uzrok, bude sumnju na malignu bolest. Promene u usnoj duplji mogu biti prvi znak maligniteta (slika 4).

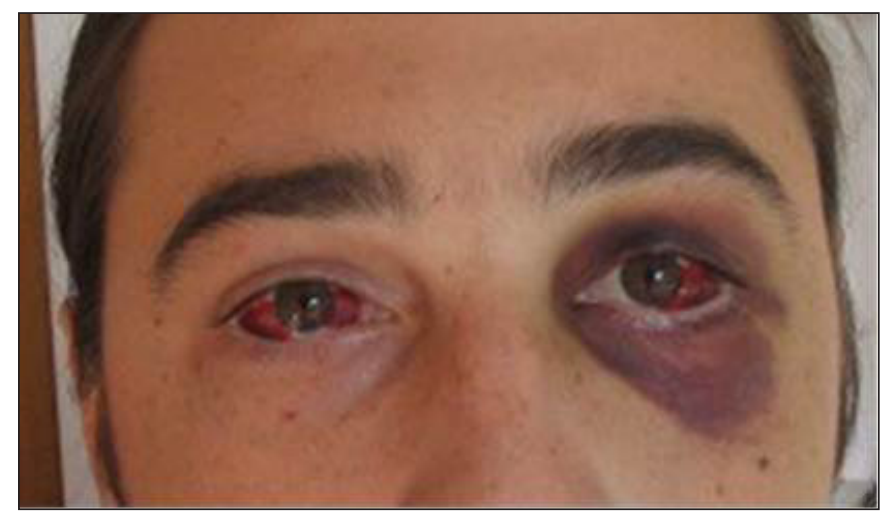

Slika 2. Bilateralno konjunktivalno krvarenje i periorbitalni hematom kod dečaka sa AML.

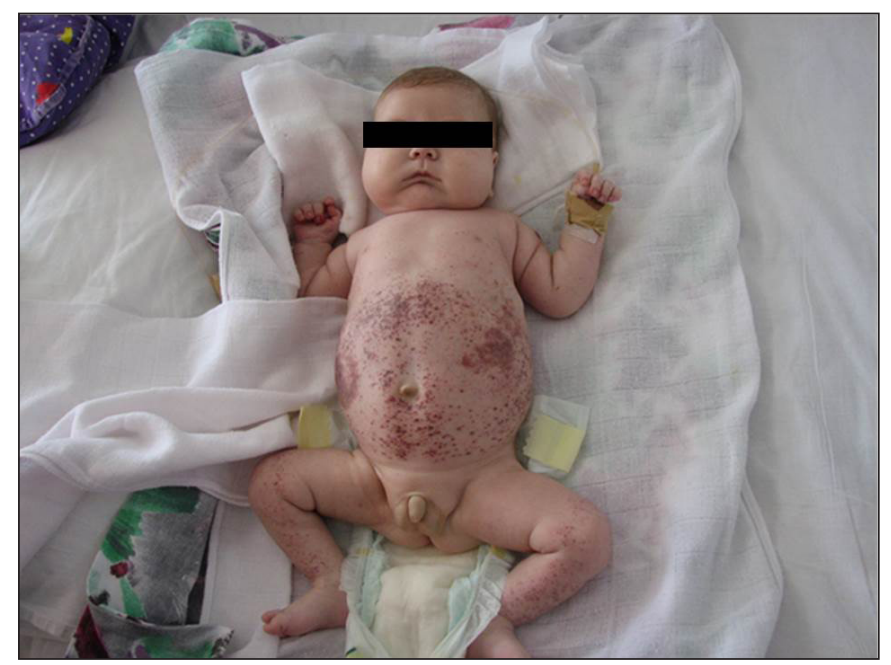

Slika 3. Slivene petehije kod muškog odojčeta sa hemofagocitnom limfohistiocitozom (HLH).

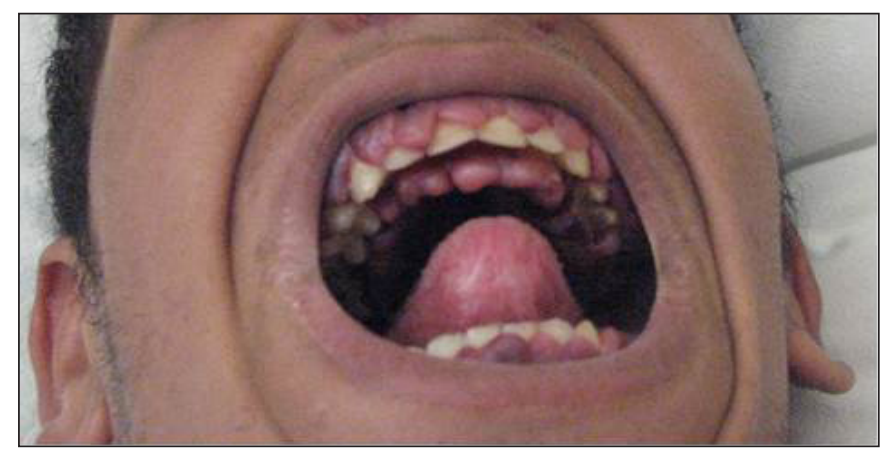

Slika 4. Infiltracija gingiva kod dečaka sa AML. 
Pojava tumefakta, dostupnog inspekciji ili palpaciji (glava, vrat, abdomen, pelvis, ekstremiteti, testisi), kao i generalizovane limfadenopatije, zahteva evaluaciju, što se vizuelizuje na slikama 5-9.

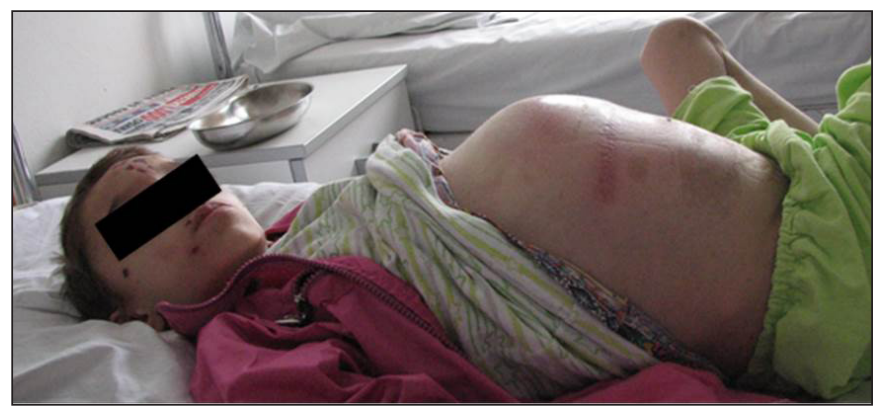

Slika 5. Masivan tumefakt $\mathrm{u}$ abdomenu kod devojčice sa embrionalnim RMS.

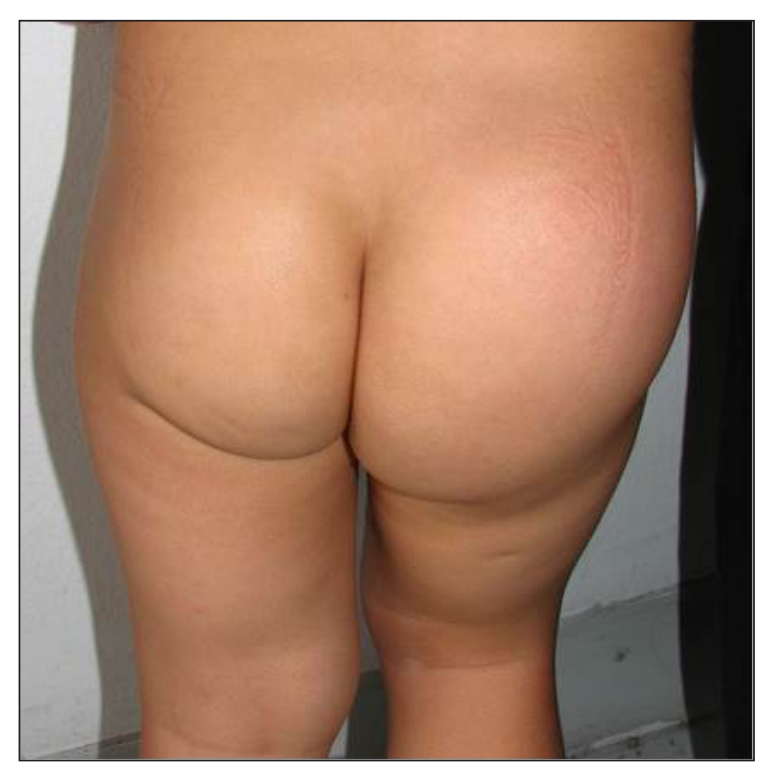

Slika 6. Unilateralni tumefakt u glutealnoj regiji kod dečaka sa alveolarnim RMS.

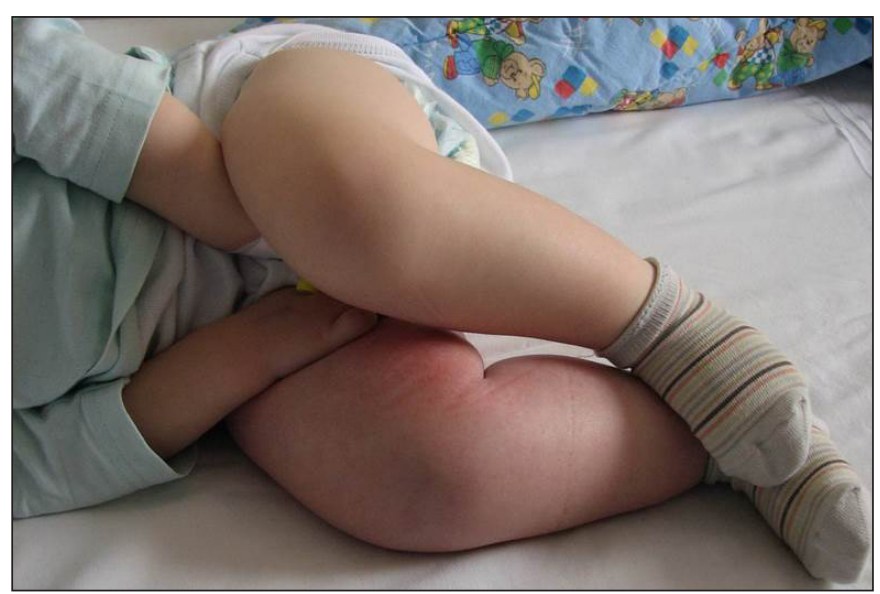

Slika 7. Tromboza leve noge izazvana kompresijom tumefakta male karlice kod dečaka sa tumorom germinativnih ćelija.

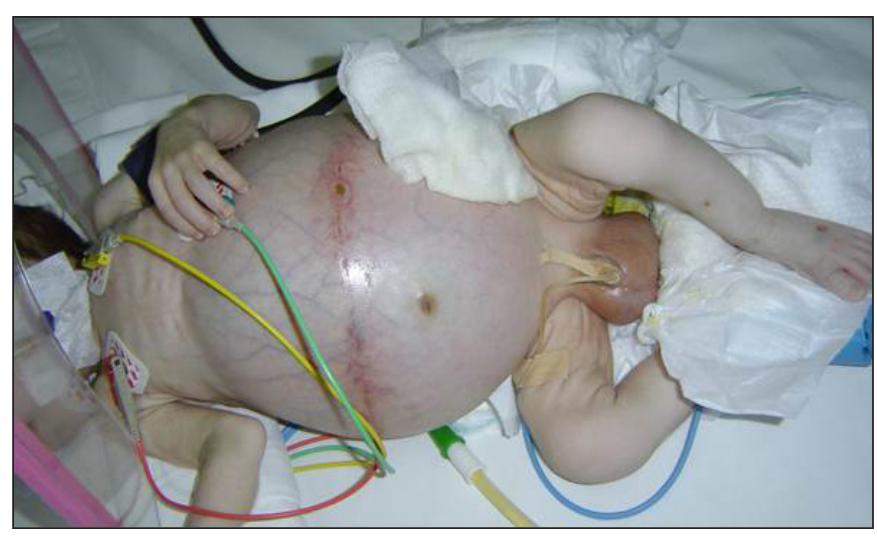

Slika 8. Abdominalni tumefakt sa brojnim metastazama u jetri kod muškog odojčeta sa NBL.

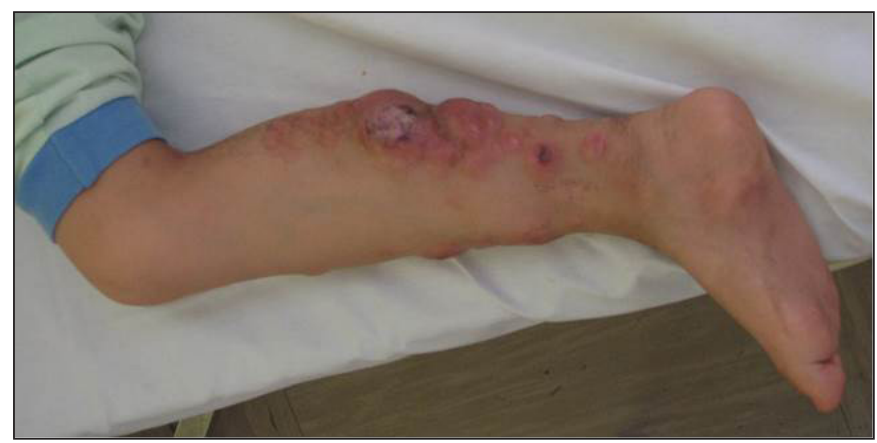

Slika 9. Tumorski infiltrat potkolenice kao neobična prezentacija Burkitt limfoma kod HIV pozitivnog dečaka.

Lokalizovana limfadenopatija je jedan od najčešćih uzgrednih nalaza u pedijatriji - u skoro polovine dece se na redovnim pregledima palpiraju limfni čvorovi, koji nemaju maligni karakter. Posledica su najčešće infekcija gornjih respiratornih puteva, ili infektivnih procesa u usnoj duplji. Međutim, unilateralna limfadenopatija, limfni čvorovi u paketu, tvrde konzistencije, nepokretni, koji prelaze promer koji odgovara lokalizacij i uzrastu, zaslužuju pregled dečjeg hematoonkologa. Takva stanja su prikazana na slikama 10-14. Uvećanje slezine i/ ili jetre su nespecifični znaci, koji mogu da budu pristuni kod različitih stanja (infektivna mononukleoza, bolesti deponovanja, hemolizne anemije), ali mogu da budu prominentni ukazatelj na malignitet, što je prikazano na slikama 15 i 16.

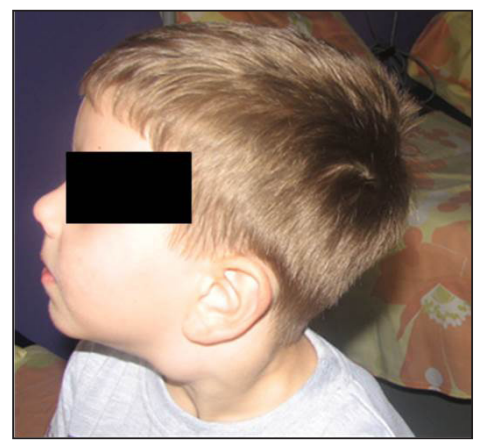

Slika 10.

Cervikalna limfadenopatija kod dečaka sa T-ćelijskim NHL. 


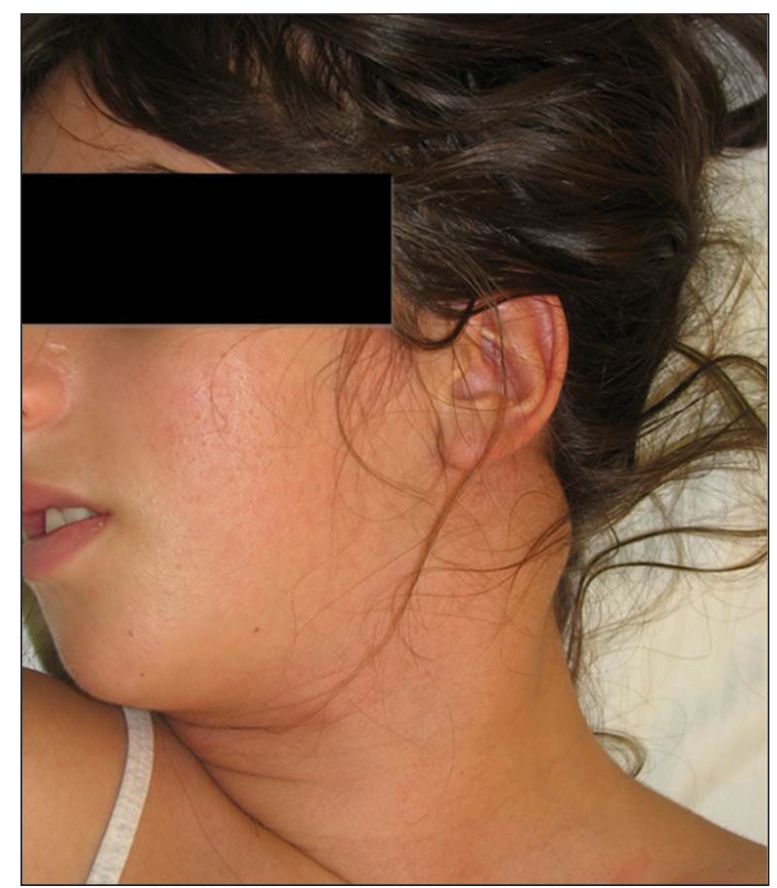

Slika 11. Unilateralna cervikalna limfadenopatija kod devojčice sa HL.

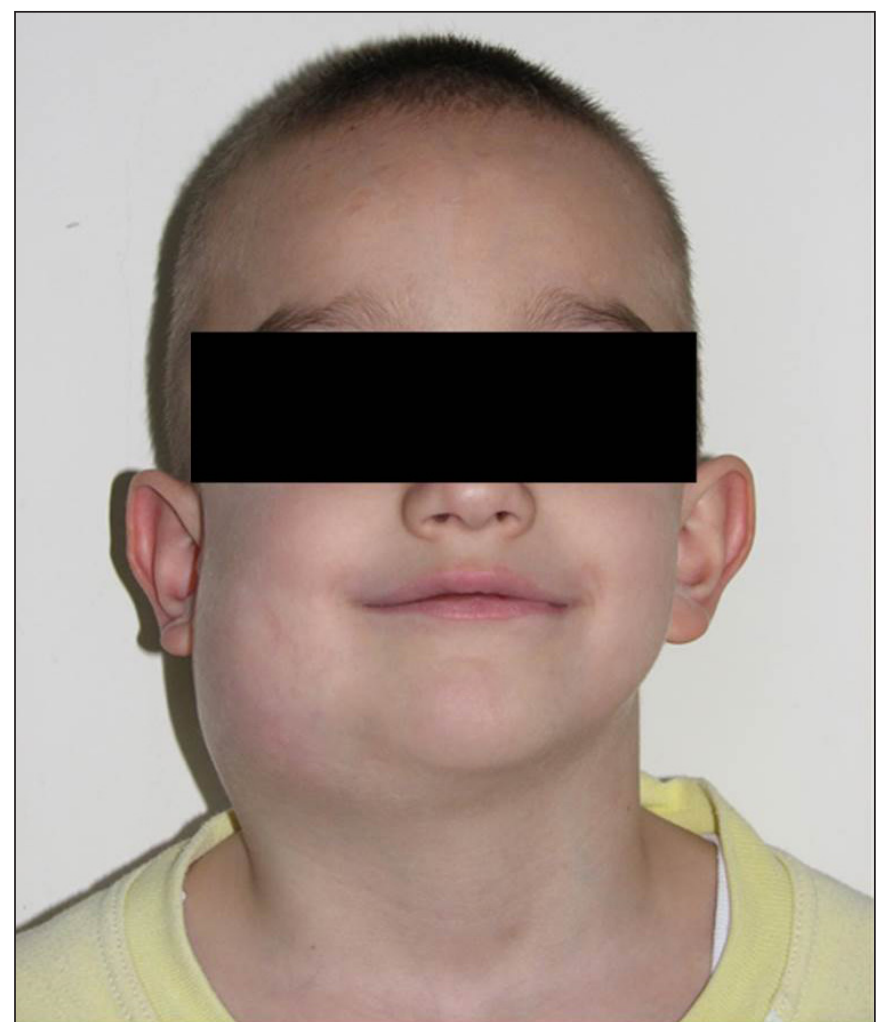

Slika 12. Unilateralna cervikalna limfadenopatija kod dečaka sa Burkitt limfomom.

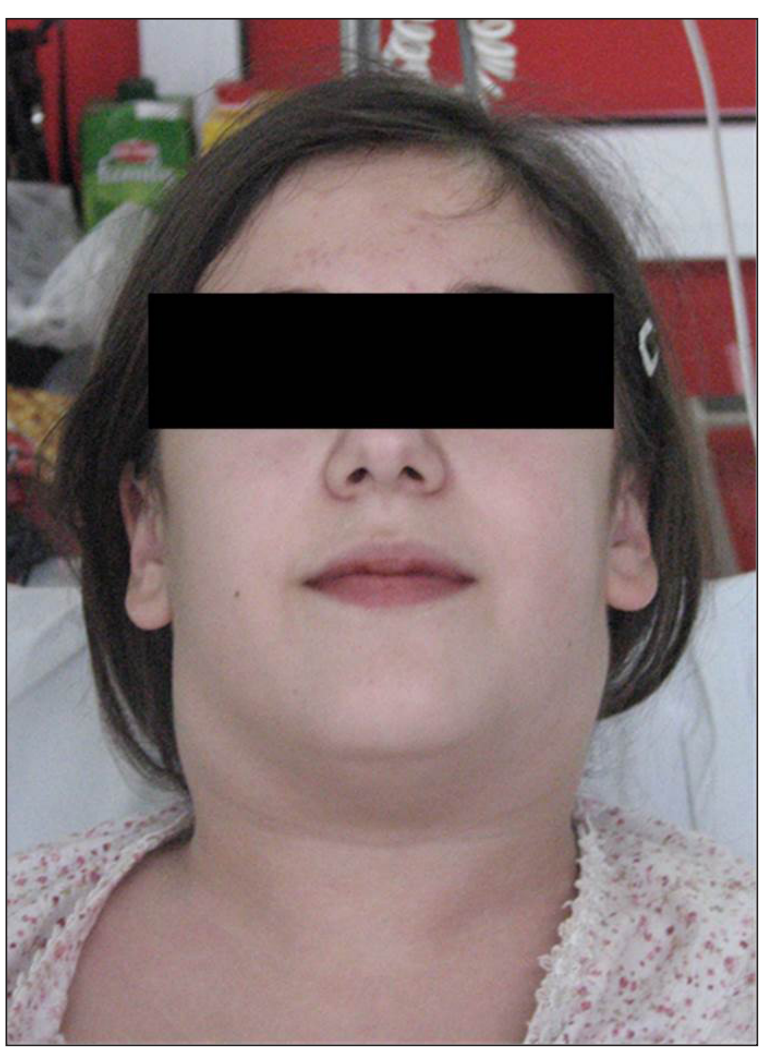

Slika 13. Bilateralna cervikalna limfadenopatija kod devojčice sa T ćelijskim NHL.

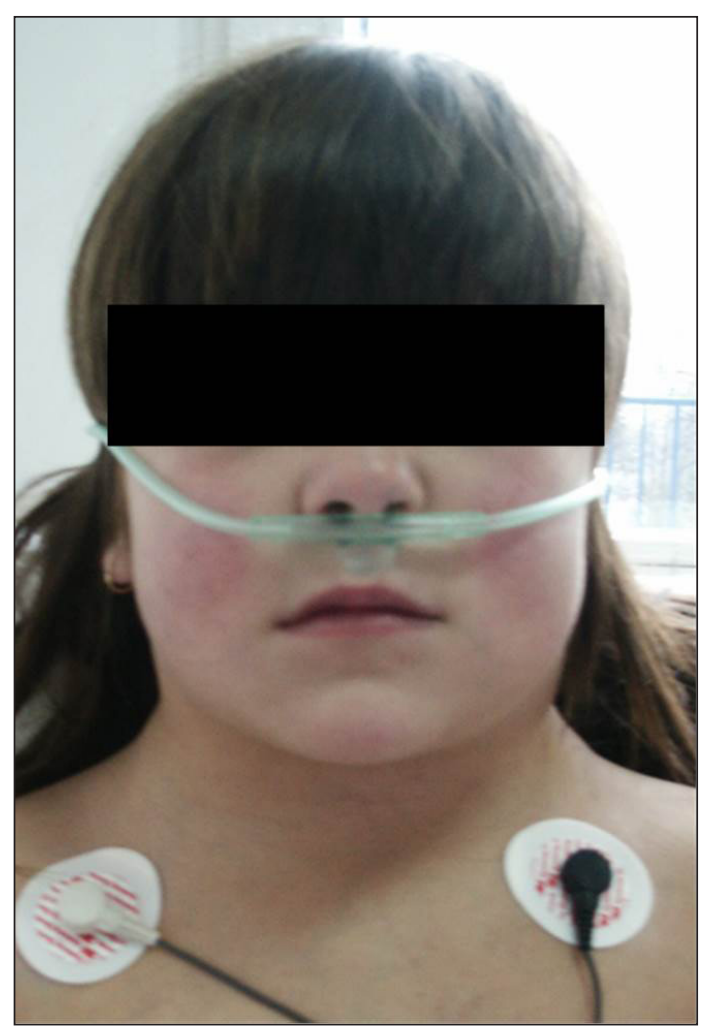

Slika 14. Sindrom gornje šuplje vene (Sy VCS) kao posledica medijastinalne mase kod devojčice sa T-ćelijskom ALL. 


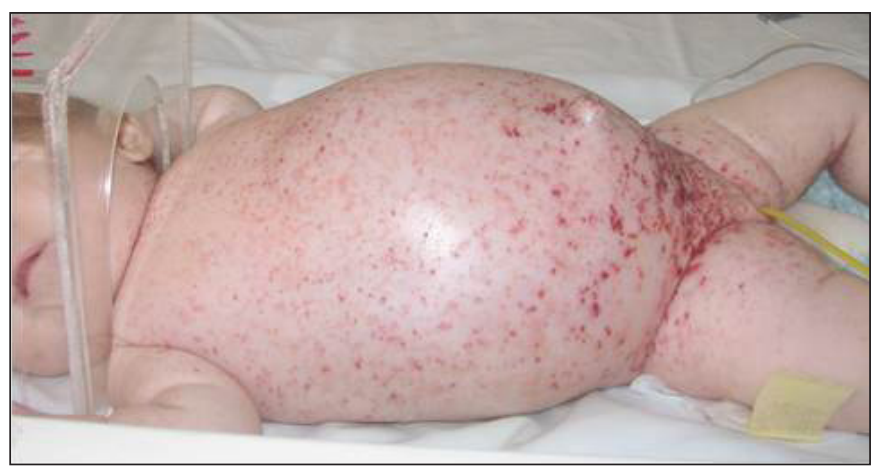

Slika 15. Hepatosplenomegalija i purpura kod ženskog odojčeta sa HLH.

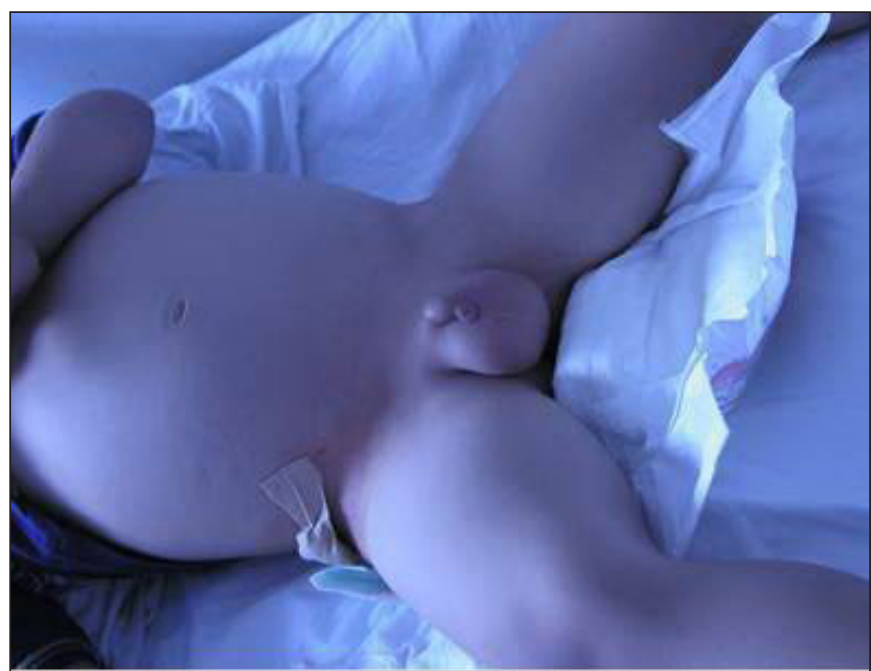

Slika 16. Hepatosplenomegalija i infiltracija testisa kod dečaka sa ALL.

Oftalmološki znaci su specifični za određene maligne bolesti. Novonastali strabizam, slepilo, protruzija bulbusa, hematom ispod oka (nezavisan od udarca), leukokorija, ptoza, diplopije pobuđuju sumnju na maligni proces. Opisane promene su prikazane na slikama 17- -22. Takođe, neurološki ispadi u vidu promene ponašanja, ravnoteže, hoda, razvoja, glavobolje i porasta lobanje su simptomi i znaci koji mogu da budu prominentni kod malignih bolesti u dece.

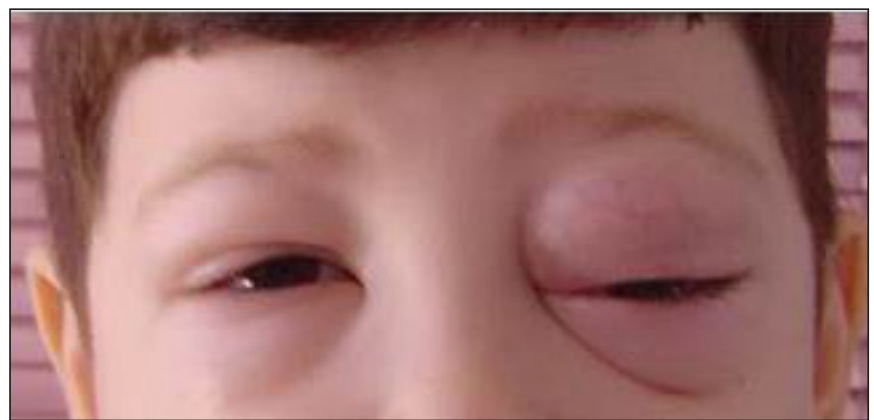

Slika 17. Retrobulbarna lokalizacija kod dečaka sa Burkitt limfomom.

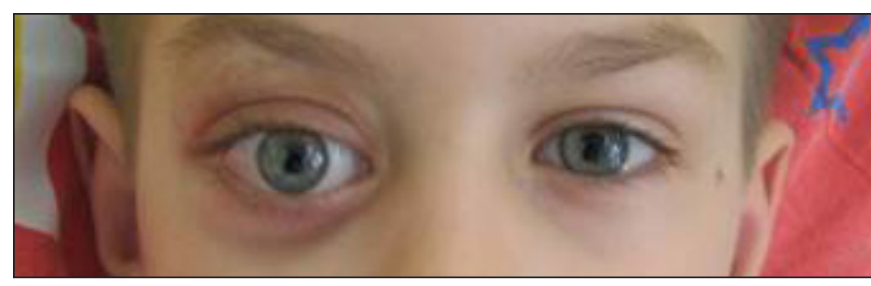

Slika 18. Ekstramedularna lokalizacija kod dečaka sa AML.

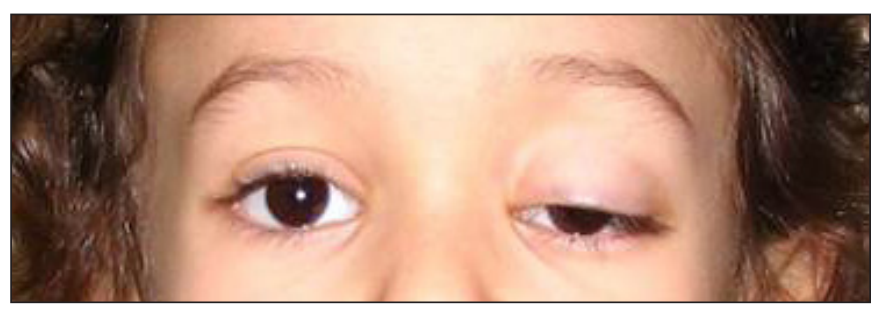

Slika 19. Ptoza kapka kod dečaka sa kraniofaringealnom lokalizacijom alveolarnog RMS.

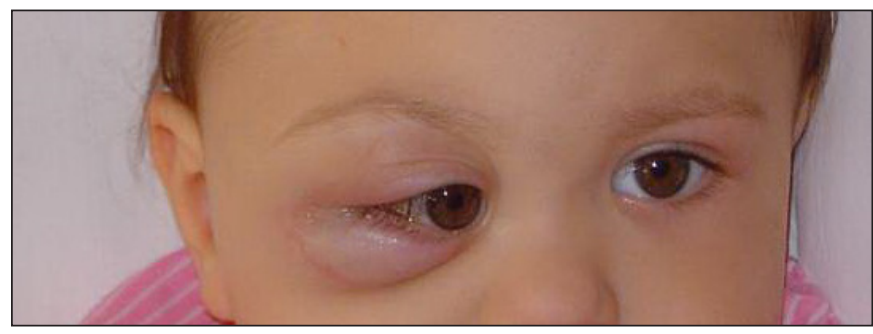

Slika 20. Retrobulbarno lokalizovane metastatske promene kod devojčice sa NBL.

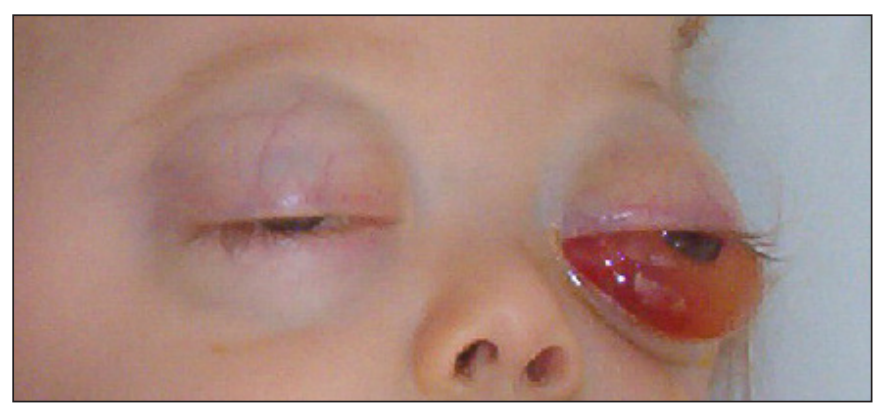

Slika 21. Ekstramedularna forma AML kod muškog odojčeta.

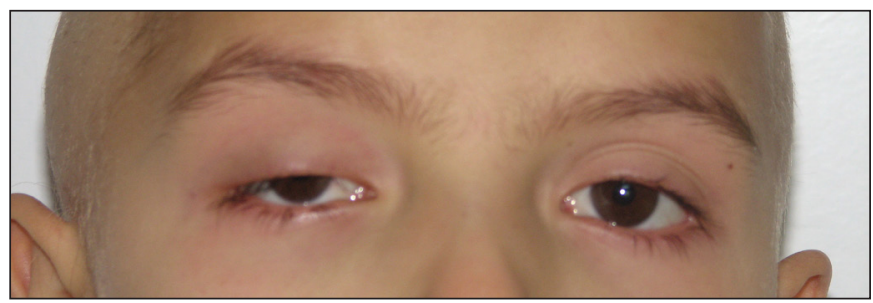

Slika 22. Ptoza kapka kod devojčice sa metahronim Wilms tumorom.

Šema za rano prepoznavanje malignih bolesti u dece, koja je u upotrebi kako u svetu, tako i kod nas, predstavljena je na tabeli 4 [16]. 
Tabela 4. „Child cancer” šema za prepoznavanje prvih simptoma i znaka maligne bolesti u dece.

\begin{tabular}{|c|c|c|}
\hline $\mathrm{C}$ & Continued, unexplained weight loss & Kontinuiran, neobjašnjiv gubitak telesne težine \\
\hline $\mathbf{H}$ & Headaches, often with early morning vomiting & $\begin{array}{l}\text { Glavobolje, često praćene povraćanjem rano } \\
\text { ujutru }\end{array}$ \\
\hline $\mathbf{I}$ & $\begin{array}{l}\text { Increased swelling or persistent pain in the } \\
\text { bones, joints, back, or legs }\end{array}$ & $\begin{array}{l}\text { Otok ili perzistentan bol u kostima, zglobovima, } \\
\text { leđima ili nogama }\end{array}$ \\
\hline $\mathbf{L}$ & $\begin{array}{l}\text { Lump or mass, especially in the abdomen, } \\
\text { neck, chest, pelvis, or armpits }\end{array}$ & $\begin{array}{l}\text { Tumefakt, posebno u abdomenu, vratu, grudnom } \\
\text { košu ili pazuhu }\end{array}$ \\
\hline $\mathbf{D}$ & $\begin{array}{l}\text { Development of excessive bruising, bleeding, } \\
\text { or rash }\end{array}$ & Izražena pojava hematoma, krvarenja ili osipa \\
\hline $\mathbf{C}$ & Constant, frequent, or persistent infections & Kontinuirane, česte ili perzistentne infekcije \\
\hline $\mathbf{A}$ & A whitish color behind the pupil & Beličasta sjajna tačka iza zenice \\
\hline $\mathbf{N}$ & $\begin{array}{l}\text { Nausea that persists or vomiting without } \\
\text { nausea }\end{array}$ & $\begin{array}{l}\text { Mučnina koja perzistira ili povraćanje bez } \\
\text { mučnine }\end{array}$ \\
\hline $\mathbf{C}$ & Constant tiredness or noticeable paleness & Konstantan umor ili vidljivo bledilo \\
\hline $\mathbf{E}$ & $\begin{array}{l}\text { Eye or vision changes that occur suddenly and } \\
\text { persist }\end{array}$ & $\begin{array}{l}\text { Promene na očima ili u vidu, koje iznenada nastaju } \\
\text { i potom traju }\end{array}$ \\
\hline $\mathbf{R}$ & $\begin{array}{l}\text { Recurring or persistent fevers of unknown } \\
\text { origin }\end{array}$ & $\begin{array}{l}\text { Rekuretna ili perzistentna febrilnost nepoznatog } \\
\text { uzroka }\end{array}$ \\
\hline
\end{tabular}

\section{Dijagnostika pedijatrijskih maligniteta}

Kada se postavi sumnja na malignu bolest kod deteta, započinje se složen dijagnostički proces, koji nije uniforman, već se na osnovu anamneze i kliničke slike usmerava prema određenom malignitetu. Ukoliko dete nije vitalno ugroženo, kada stanje deteta diktira uslove dijagnostike, poštuje se algoritam u odnosu na bolest koja se ispituje.

Analize se usmeravaju u odnosu na sumnju na konkretnu malignu bolest, jer nije medicinski ispravno uzorkovanje velike količine krvi i anemiziranje deteta pred početak lečenja. U pedijatrijskom uzrastu postoje fiziološki varijeteti različitih analiza u odnosu na uzrast i pol, zbog čega je potrebno precizno tumačiti dobijene vrednosti [19]. Npr. broj leukocita u prvom danu života može biti fiziološki veći i do pet puta u odnosu na vrednosti u adolescenciji.

Laboratorijske pretrage uključuju krvnu sliku, biohemijske analize iz krvi, urina, likvora, tumorske markere, određene imunološke i virusološke analize, prošireni koagulacioni status, kao i citološki pregled aspirata koštane srži, likvora i tumorskog eksudata. Infiltracija koštane srži maligno alterisanim hematopoetskim i nehematopoetskim ćelijama prikazana je na slikama 23-25. U laboratorijske pretrage takođe spadaju imunofenotipizacija maligno alterisanih ćelija met-

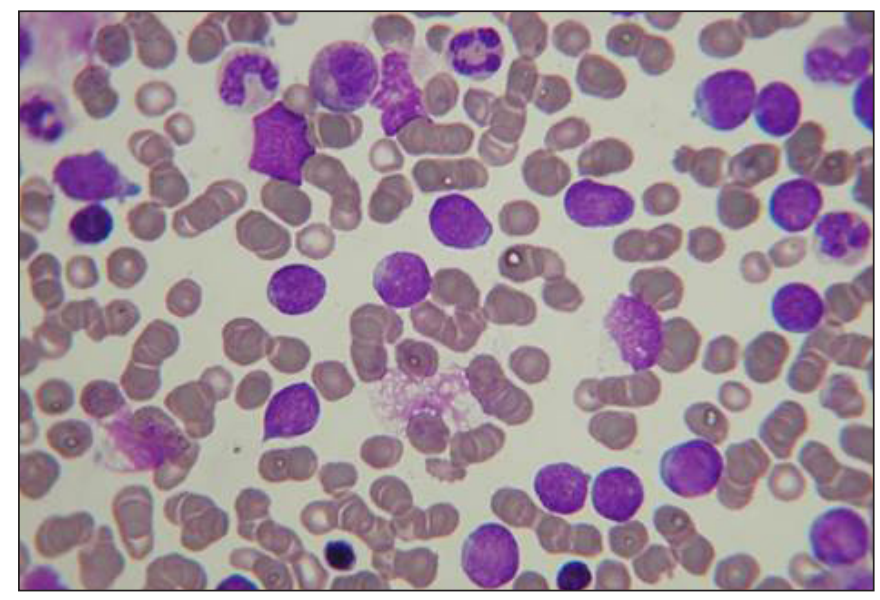

Slika 23. Infiltracija koštane srži limfoblastima kod ALL.
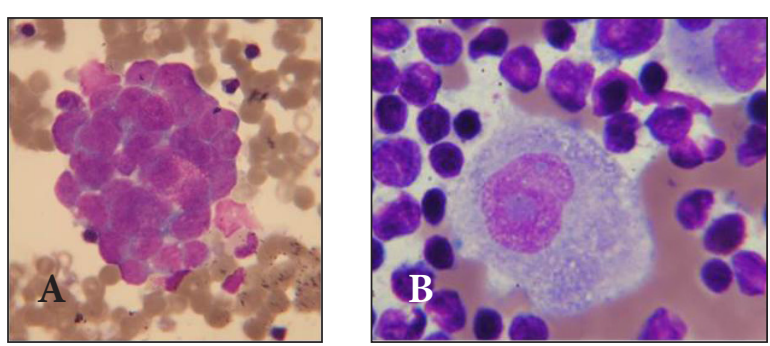

Slika 24. Infiltracija koštane srži Reed Sternberg ćelijama kod HL (A) i rozetama kod NBL (B). 


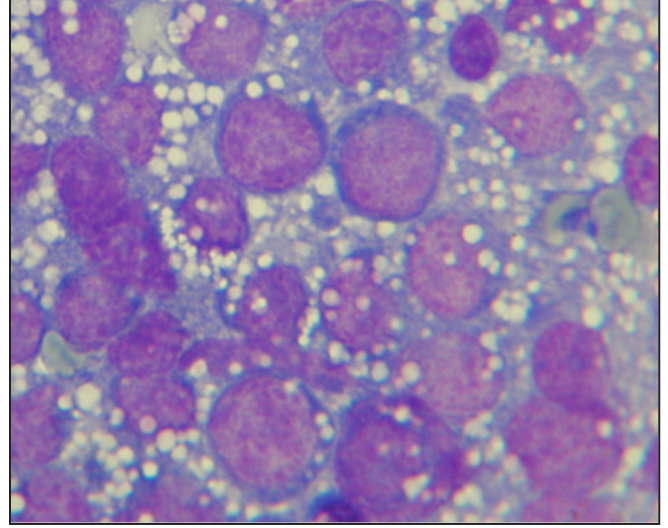

Slika 25. Tumorski eksudat kod Burkitt limfoma.

odom protočne citometrije ( $F C$ - flow citometry), citogenetske analize iz kariotipa periferne krvi ili koštane srži, molekularno genetske analize periferne krvi, koštane srži ili tumorskog tkiva. U najčešće genetske analize spadaju konvencionalna citogenetika, fluorescentna in situ hibridizacija (FISH), metoda lančane polimerizacije ( $P C R$ - polimerase chain reaction) i različiti DNK/RNK eseji [20]. Među laboratorijske analize spada i patohistološki pregled bioptata tumorskog tkiva ili koštane srži, sa imunohistohemijskim bojenjima koje bliže određuju profil maligne bolesti.

Potrebno je da se dobro informišemo da li je dete primalo određenu terapiju pre uzorkovanja određenih analiza. Ako je iz nekog razloga ordinirana kortikosteroidna terapija, pre započinjanja dijagnostike pod sumnjom na akutnu leukemiju, postoje velike šanse da se dobije lažno negativan nalaz, jer su primenjeni lekovi doveli do kratkotrajne eliminacije malignih ćelija u koštanoj srži.

Poznato je koje vrste raka dovode do patoloških vrednosti određenih laboratorijskih parametara. Kod deteta sa supraklavikularnom limfadenopatijom, koje ima izrazito povišene reaktante akutne faze zapaljenja (sedimentacija eritrocita, C-reaktivni protein, fibrinogen), postoji jasna sumnja na Hočkinov limfom (HL) i ne postoji potreba da se rade brojni tumor markeri, npr. NSE (neuron-specifična enalaza), koji je najčešće povišen kod neuroblastoma (NBL) ili AFP (alfa feto protein), koji je marker tipičan za hepatoblastom (HBL). Ukoliko postoji poremećaj sve tri loze u krvnoj slici, verovatna je dijagnoza akutne leukemije i takođe ne postoji potreba da se radi npr. $\beta$ HCG (beta humani horionski gonadotropin), koji može biti povišen kod tumora germinativnih ćelija. Ako postoji sumnja na HBL ili rabdomiosarkom (RMS), nema potrebe za aspiracionom punkcijom koštane srži, jer je to tumor koji je ne infiltriše.

Analize nisu bitne samo u konkretnoj dijagnostici, već značajno pomažu u preciznoj stratifikaciji stadiju- ma/grupe rizika. Vrednost LDH (laktat dehidrogenaze) učestvuje u definisanju grupa rizika kod NHL, prisustvo BCR/ABL transkripta u dece sa ALL direktno ih stratifikuje u grupu visokog rizika [21], deca kod koje je viđeno prisustvo tumora na liniji resekcije u patohistološkom nalazu se leče intenzivnijim terapijskim modalitetima. Takođe, analize koje se inicijalno izvode mogu se kasnije ponavljati kada je potrebno da se proceni odgovor na primenjenu terapiju, odnosno da se prati minimalna rezidualna bolest (MRD - minimal residual disease) [22]. A sa druge strane, određene analize služe praćenju toksičnosti ordiniranih lekova u cilju da se prema farmakokinetskim i farmakogenetskim osobinama pacijenta pristupi indivudualnom doziranju citostatske terapije [23].

Radiološke pretrage su, pored laboratorijskih, neophodne $\mathrm{u}$ dijagnostici malignih bolesti, ne samo u smislu lokalizacije tumora i stepena njegove zahvećenosti okolnih struktura, već i zbog pravilnog određivanja stadijuma, odnosno procene raširenosti bolesti. Npr. jasno prisustvo infiltracije osnovne bolesti ispod dijafragme kod dece sa Hočkinovim limfomom ih svrstava $\mathrm{u}$ više kliničke stadijume bolesti. Radiološke metode, koje se koriste u dijagnozi pedijatrijskih maligniteta su: radiografija (RTG - slike 26 i 27), ultrazvuk (UZ - slike 28 i 29), kontrastna multislajsna kompjuterizovana tomografija (MSCT - slike 30 i 31), nuklearna magnetna rezonanca (NMR - slike 32 i 33), radioizotopska scintigrafija (MIBG - metaiodobenzilguanin - slika 34), pozitronska emisiona tomografija (PET-SCAN). Maksimalno se izbegava prekomerno snimanje i optimizuje se način radiološkog praćenja odgovora na primenjenu terapiju, jer su savremene studije ukazale na povećan broj maligniteta kod dece koja su prethodno bila izložena x-zračenju [24].

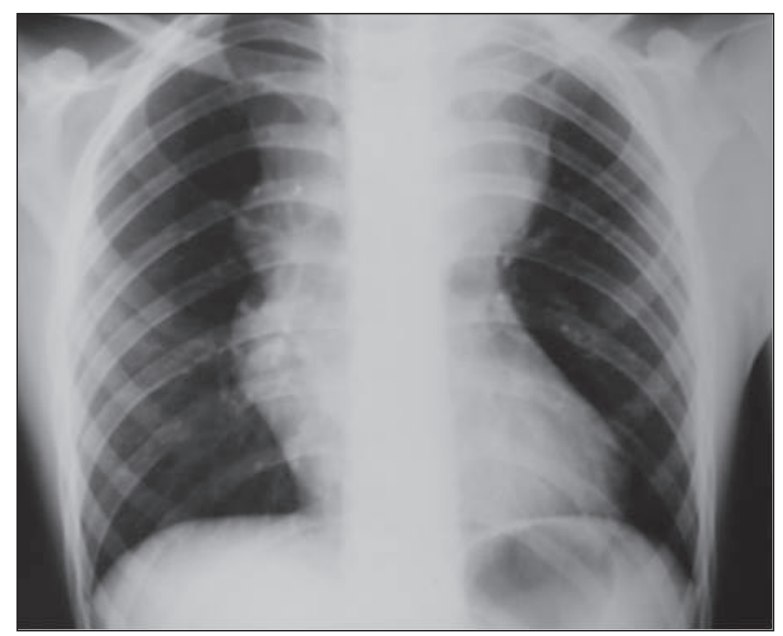

Slika 26. Medijastinalna masa kod dečaka sa T-ćelijskom ALL. 


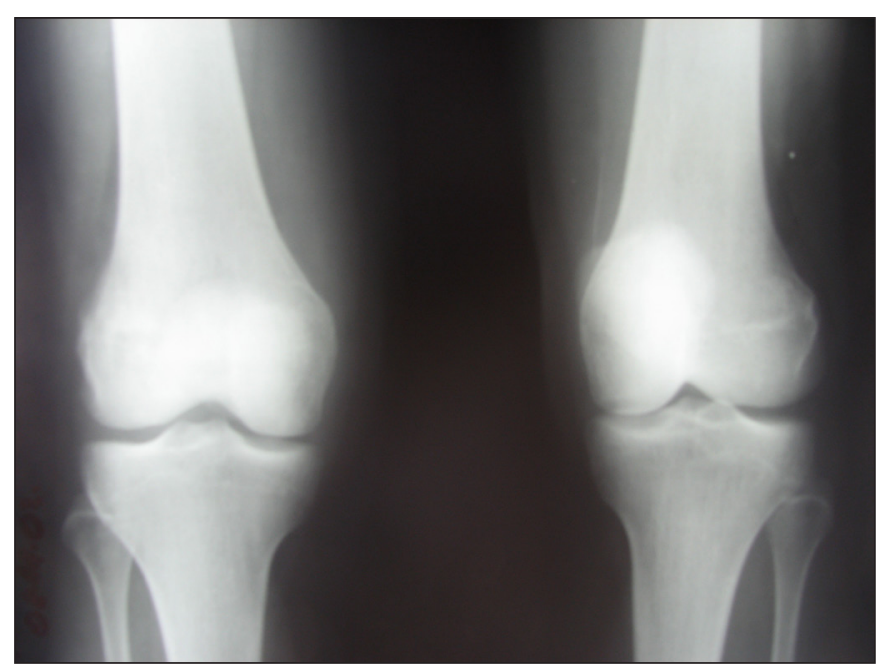

Slika 27. Infiltracija distalnog dela femura kod devojčice sa primarnim koštanim B ćelijskim NHL.

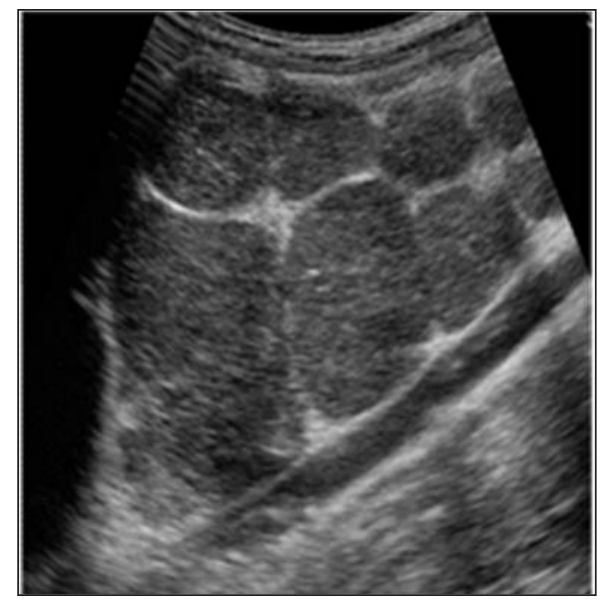

Slika 28. Cervikalna limfadenopatija kod T-ćelijskog NHL.

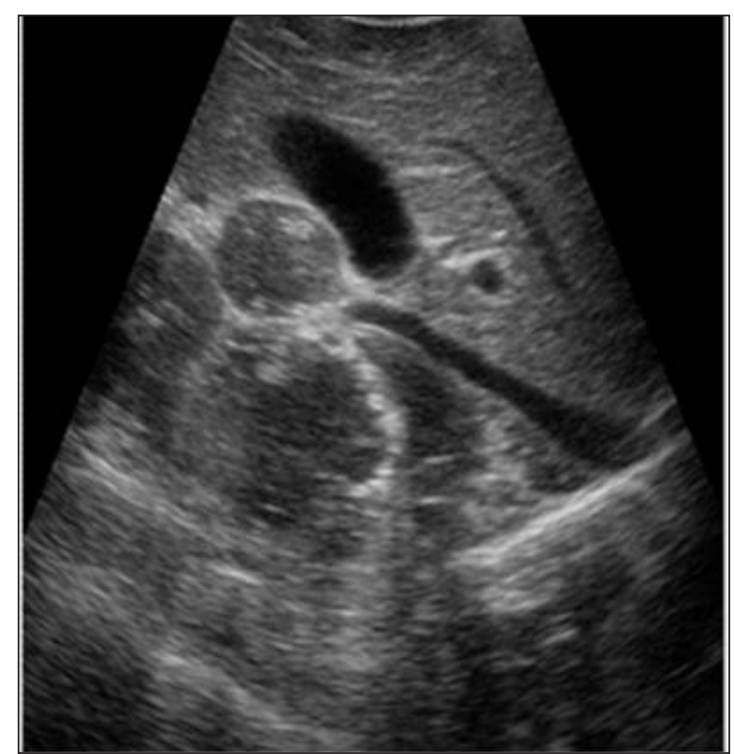

Slika 29. Retroperitonealna limfadenopatija kod NBL.

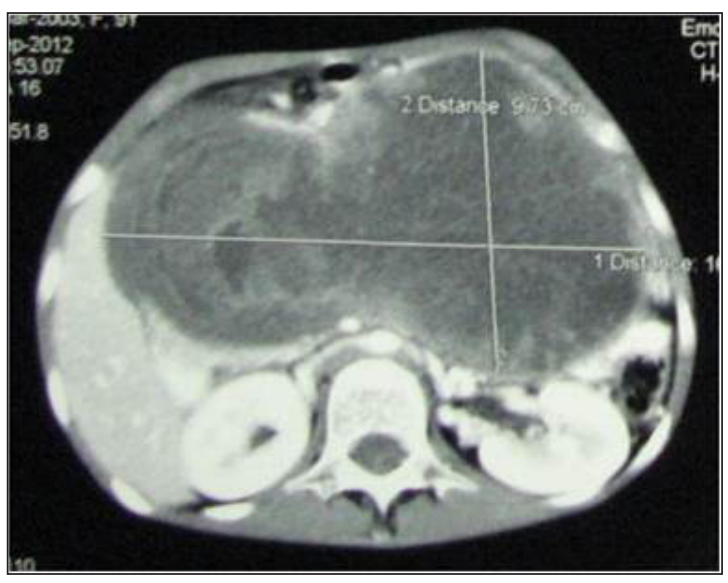

Slika 30. Abdominalni RMS.

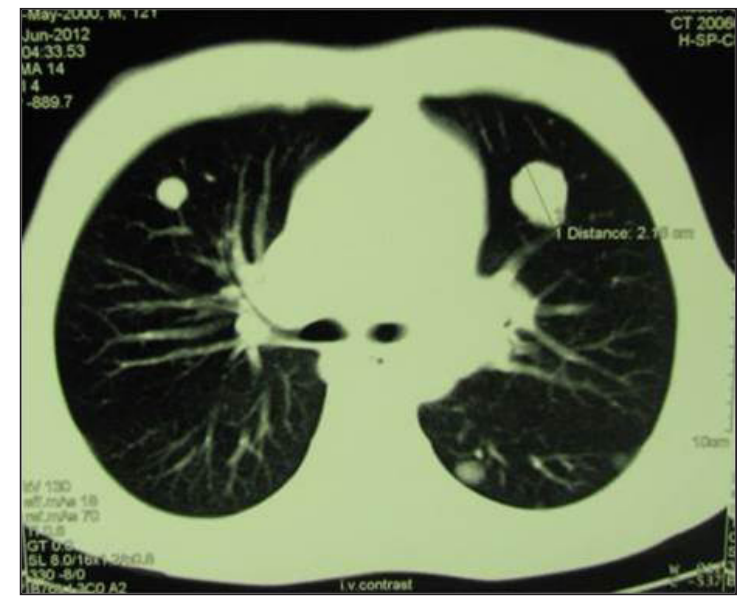

Slika 31. Pulmonalne metastaze kod primarnog abdominalnog adrenokortikalnog karcinoma (ACC).

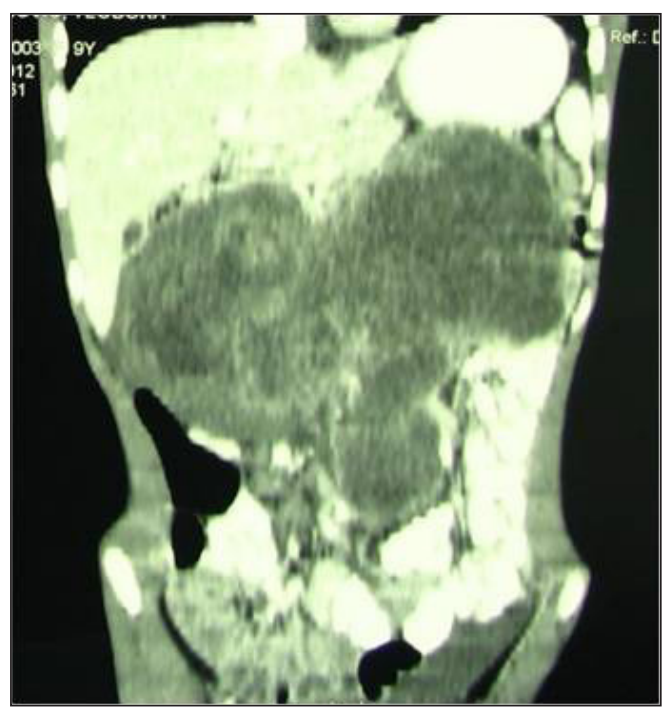

Slika 32. Abdominalni RMS. 


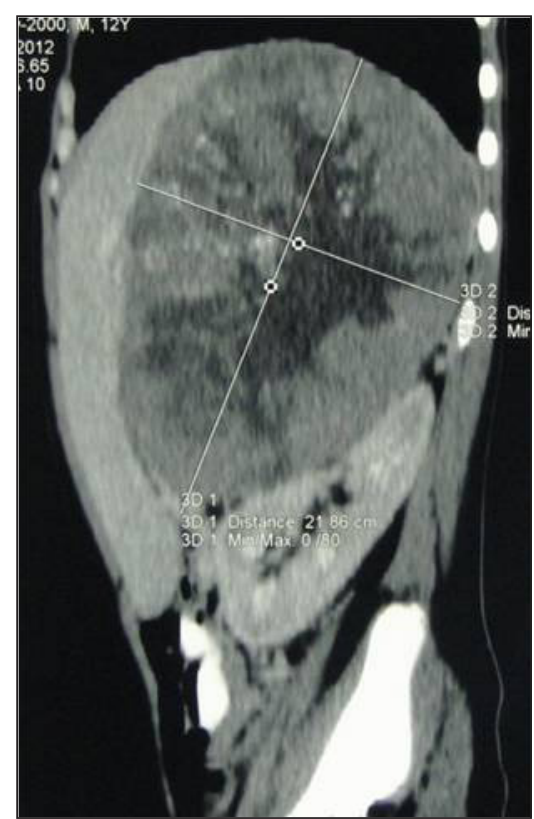

Slika 33. ACC.

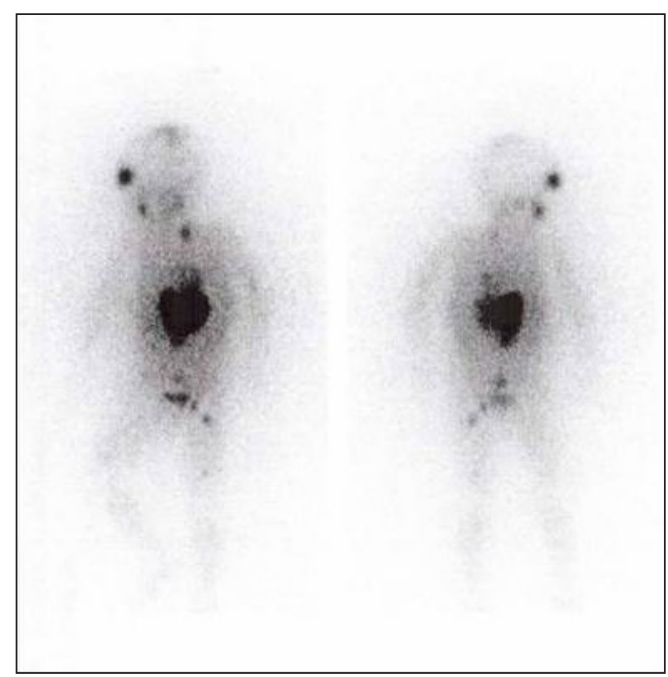

Slika 34. Nakupljanje radiofarmaka kod metastatskog NBL.

\section{Lečenje malignih bolesti kod dece}

Lečenje malignih bolesti u pedijatrijskom uzrastu je vrlo kompleksno i sprovodi se u specijalizovanim tercijarnim centrima. Jedna od osnovnih strategija lečenja dece je da provedu što manje vremena u bolnici, zbog čega većina dece, kada to stanje dozvoli, prima terapiju preko dnevne bolnice.

U našoj zemlji postoji pet centara koji se bave dijagnostikom i lečenjem raka u dece. Svi lekari, uključeni u dijagnostiku i lečenje, prošli su obuku u zemlji i inostranstvu, i članovi su IODHOI (Intersekcijski odbor za dečju hematologiju, onkologiju i imunologiju), nacio- nalne grupe, koja je deo internacionalnih udruženja za lečenje pedijatrijskih maligniteta.

Kako je smrtnost u pedijatrijskoj populaciji sa malignim bolestima početkom 20 . veka bila skoro $100 \%$, prepoznata je potreba da se znanja i iskustva sjedine, s obzirom na to da se radi o retkim bolestima. Tako je krajem 1960. godine osnovan SIOP (The International Society of Paediatric Oncology), koji danas broji 1000 članova širom sveta, među kojima su i lekari IODHOI [25]. Hansjorg Riehm (Berlin, Nemačka) je 1970. godine napravio "BFM koncept lečenja", koji je doveo do revolucionarnog porasta u procentu preživljavanja dece sa ALL. Godine 1975. zajedno sa Bernhardom Kornhuherom (Frankfurt) i Guntherom Schellongom (Minhen) osniva BFM grupu (Berlin-Frankfurt-Minhen), kada je otpočeta i prva multicentrična studija. Internacionalizacija BFM grupe (I-BFM) nastaje 1987. godine, kada se Nemačkoj pridružuju i druge nacionalne grupe za lečenje limfoproliferativnih bolesti kod dece: Austrija (BFM), Francuska/ Belgija (EORTC-CLG), Nemačka (BFM), Italija (AIEOP) i Holandija (DCLSG). I-BFM danas broji 34 zemlje članice i 400 aktivnih članova [26]. Srbija je od 2002. godine punopravna članica I-BFM grupe i učestvuje u internacionalnim studijama. Randomizovane studije su najefikasniji i jedini etički opravdan način kritičke evaluacije novih načina lečenja malignih bolesti.

Sa istorijskog aspekta, prva terapijska opcija u lečenju raka je bila hirurgija, davne 1900. godine, koja i danas zauzima značajno mesto, kako u dijagnostici, tako i u lečenju [27]. Prva hemioterapija (HT) je primenjena 1940. godine [28]. Citostatici su različite grupe lekova sa drugačijim mehanizmom dejstva na ćelijski ciklus i funkcije maligno izmenjene ćelije. Radioterapija (RT) je deo lečenja od 1950. godine, sa primenom različitih doza zračenja u odnosu na vrstu i lokaciju maligne bolesti [29]. Prva transplantacija matičnim ćelijama hematopoeze (TMĆH) je učinjena 1960. godine [30]. Tokom pola decenije, korigovane su doze i režimi primene, kako HT, tako i RT, kao i indikacije za TMĆH, što je dovelo do značajnog napretka u preživljavanju. Biološka terapija je otpočeta 1990. godine, što je takođe doprinelo povećanom procentu izlečenja [13]. Najnoviji terapijski modalitet, u vidu imunoterapije, koji je u primeni od 2010. godine, na osnovu preliminarnih rezultata tekućih studija ostvaruje velika očekivanja [31]. Intenzivno lečenje se ne može sprovoditi bez dobre suportivne terapije, a poseban entitet u lečenju je i palijativna nega kod bolesnika u terminalnoj fazi lečenja. Najsavremeniji terapijski koncept podrazumeva individualizaciju lečenja, na osnovu precizno stratifikovane grupe rizika/stadijuma, genetskog profila bolesnika i kvantifikacije merenja odgovora na terapiju.

Protokoli za različita oboljenja se međusobno 
dosta razlikuju, ali deca obolela od iste bolesti, mogu da imaju različit režim lečenja, zavisno od stadijuma/ grupe rizika. Protokol predstavlja raspored primene HT, RT, BT i TMĆH u lečenju jednog oboljenja. Koji će modaliteti lečenja biti primenjeni (da li samo medikamentozno lečenje $\mathrm{i} / \mathrm{ili}$ operativno, zračno, transplantaciono i biološko) zavisi takođe od stadijuma/grupe rizika, kao i genetskog profila bolesnika. Mogući načini primene brojnih citostatika su: peroralni, intravenski (u vidu bolusa ili kratkotrajne/dugotrajne infuzije), subkutano, muskularno i intratekalno. RT ne podležu sva deca, sprovodi se samo kod određene grupe dece, što je jasno determinisano protokolom lečenja. Doza RT može biti preventivna (manja) i terapijska (veća), a u pripremi za alo-TMĆH se sprovodi TBI (total body irradiation - zračenje celog tela). TMĆH se uglavnom radi kod dece koja spadaju u grupu visokog rizika/odmaklog stadijuma ili kod dece koja su razvila recidiv osnovne bolesti. Donor kod alogene TMĆH može biti od srodna ili nesrodna osoba, uz maksimalno ispunjen kriterijum HLA tipizacije za podudarnost lokusa. Izvor grafta kod alogene TMĆH može biti koštana srž, periferna ili umbilikalna krv zdrave osobe, dok je izvor grafta kod autologe TMĆH koštana srž pacijenta.

Trajanje lečenja takođe zavisi od dijagnoze osnovne bolesti i stepena njene raširenosti, kao i procene odgovora na već primenjenu terapiju: npr. leukemije se leče oko 2 godine, dok se većina solidnih tumora leči u proseku oko 6-9 meseci. Mogući ishodi su: kompletno izlečenje, bolest pod kontrolom (parcijalan odgovor na primenjene modalitete lečenja), recidiv (ponovna pojava bolesti nakon izlečenja), progresija bolesti (porast tumorskog resta, koji je prethodno bio pod kontrolom) ili metastatski proces, terminalna faza i smrt [32].

\section{Komplikacije lečenja dece obolele od raka}

Kao što je već pomenuto u uvodnim pasusima, stopa preživljavanja dece obolele od raka je vrlo visoka. Međutim, lečenje je povezano sa brojnim komplikacijama, a broj i intenzitet komplikacija zavisi od grupe rizika i stadijuma bolesti. Što je viši stadijum/grupa rizika, to je veći broj primenjenih lekova i njihova kumulativna doza. Takođe, uznapredovala bolest utiče na broj operacija i stepen njihove mutilantnosti. Sa odmaklim stadijumom/ grupom rizika raste i potreba za RT i TMĆH, koje su, obe, povezane sa dodatnim sekvelama. Raširenost bolesti značajno smanjuje procenat preživljavanja i povećava troškove lečenja. Najnoviji podaci velikih internacionalnih studija ukazuju da čak oko $60 \%$ adulta ima makar jedan hroničan problem kao posledicu lečenja maligniteta u pedijatrijskom uzrastu, a 30\% dugotrajne sekvele [7].

Komplikacije se dele na urgentne, akutne i kasne.
Urgentne komplikacije nastaju od same bolesti: sindrom lize tumora kod hiperleukocitoze u ALL, sindrom gornje šuplje vene kod limfoma lokalizovanog u prednjem medijastinumu, diseminovana intravaskularna koagulopatija (DIK) kod promijelocitne leukemije, kompresija različitih tumora na vitalne organe. Akutne komplikacije mogu da budu blage i životno ugrožavajuće, a kasne mogu da budu prolazne i trajne. Akutne komplikacije se dele po zahvaćenim organima i sistemima i tako su predstavljene na tabeli 5. Kasne komplikacije takođe zahvataju brojne organe i sisteme, na prvom mestu: bubrege, jetru, štitastu žlezdu, utiču na neurološki, hormonski i kognitivni status [33].

Jedna od ključnih briga roditelja dece obolele od raka jeste pitanje njihovog potomstva. Plodnost je vrlo verovatna kod većine pacijenata nakon završenog lečenja, ali nije zagarantovana. Zavisi od stadijuma/grupe rizika, a samim tim i modaliteta lečenja. Operativni zahvat u cilju izlečenja maligne bolesti koji direktno ugrožava fertilitet (npr. orhiektomija, ovariektomija), zračna terapija pelvisa, primena određenih citostatskih agenasa i TMĆH, značajno smanjuju šanse za potomstvo. Postoji mogućnost da se izvrši krioprezervacija jajnih ćelija ili semene tečnosti pre početka lečenja, u cilju kasnije fertilizacije [34].

Potreba da se deca koja se izleče od raka prate kroz dug vremenski period, od strane visoko specijalizovanih lekara, odavno je prepoznata. Iz tog razloga su oformljene internacionalne grupe za praćenje kasnih efekata lečenja pedijatrijske populacije sa malignim bolestima i kada pređu u adultni uzrast. Jedna od najprominentnijih je PanCare (Pan-European network of professionals, survivors and their families) koja kroz odgovarajuće platforme, kao što je npr. LESS (Late effects surveillance system) registruje sve neželjene efekte terapije i pravi brojne programe koji imaju za cilj da spreče ili ublaže ozbiljne sekvele lečenja i održe adekvatan kvalitet života [35].

\section{Psihosocijalna reintegracija}

Kako je lečenje, a potom i praćenje dece obolele od raka dugotrajno, ulažu se veliki napori da se deci i roditeljima olakšava taj period. Povratak u život pre bolesti deteta nije jednostavan. Uspešna reintegracija se odnosi, kako na samo bolesno dete, tako i na roditelje i drugu decu u porodici (braća i sestre).

Decom sa malignim bolestima se bavi multidisciplinarni tim, koji sačinjavaju lekari, subspecijalisti pedijatrijske hematologije, onkologije i imunologije, visoko obučen srednji medicinski kadar, nutricionisti, psiholozi, socijalni radnici, vaspitači, nastavnici, brojni volonteri koji prolaze specijalnu edukaciju od strane lekara i psi- 
Tabela 5. Akutne komplikacije lečenja dece sa malignim bolestima.

\begin{tabular}{|c|l|}
\hline Kardiorespiratorne & Traheobronhijalna kompresija, tamponada srca \\
\hline Gastrointestinalne & Oralni mukozitis, ezofagitis, gastritis, ulkus, tiflitis, akutni pankreatitis \\
\hline Renalne & Akutna bubrežana insuficijencija, tubulopatije, proteinurija \\
\hline Hepatične & Akutna hepatična insuficijencija \\
\hline Neurološke & Posteriorni reverzibilni encefalopatski sindrom, encefalopatija \\
\hline Mišićno-skeletne & Osteopenija, osteoporoza, osteonekroza \\
\hline Metaboličke & $\begin{array}{l}\text { Kušingoidni sindrom, elektrolitni i acido-bazni disbalansi, sindrom } \\
\text { neadekvatne sekrecije ADH }\end{array}$ \\
\hline Hematološke & Anemija, trombocitopenija, neutropenija, poremećaji hemostaze \\
\hline Medikamentozne & $\begin{array}{l}\text { Vinkrinstinska neuropatija, alergija na L-asparaginazu/hemoprodukte, } \\
\text { steroidni dijabetes, metotreksatna toksičnost, veno-okluzivna bolest } \\
\text { jetre }\end{array}$ \\
\hline Infektivne & $\begin{array}{l}\text { Febrilna neutropenija, sepsa, invazivna gljivična infrekcija, hepatitis } \\
\text { B/C, HIV }\end{array}$ \\
\hline Hiruške & $\begin{array}{l}\text { Kompresija tumorom, komplikacije vezane za centralni venski kateter, } \\
\text { postoperativne komplikacije }\end{array}$ \\
\hline Opšte & Alopecija, kaheksija, malaksalost \\
\hline Depresija, agitiranost, suicidalni pokušaji, agresija prema bližoj okolini \\
\hline
\end{tabular}

hologa i udruženja koja imaju za cilj da pruže deci radost i relaksaciju tokom hospitalnog lečenja [36].

Kvalitet života, tokom i nakon lečenja, imperativ je multidisciplinarnog tima. Jedna od prvih stavki koja obezbeđuje zdravu psihosocijalnu reintegraciju je školovanje. Insistira se na tome da deca ne gube od nastave, kada god to medicinski uslovi dozvoljavaju, a kada odlazak u kolektiv nije indikovan, praktikuje se nastava u bolničkim ili kućnim uslovima [37]. U našoj sredini je omogućeno pohađanje osnovne škole, a radi se na tome da se obezbedi i mogućnost školovanja za srednju stručnu spremu.

Unazad nekoliko godina, $\mathrm{u}$ organizaciji $\mathrm{Na}-$ cionalnog udruženja roditelja dece obolele od raka (NURDOR), deca iz Srbije učestvuju u nacionalnim i internacionalnim kampovima namenjenim bolesnicima koji se leče od malignih bolesti [38]. U istoj organizaciji se održavaju i kampovi podrške za braću i sestre dece obolele od raka [39]. U bolnicama se organizuju radionice za podršku roditeljima, kada se nakon radnog vremena svi članovi multidisciplinarnog tima, svako iz svog ugla, bave problemima sa kojima se susreću roditelji tokom lečenja svog deteta od maligne bolesti.

\section{Literatura}

1. Brooks M, Chustecka Z i sar. Top news from ECC 2013 (ECCO-ESMO-ESTRO) on http://www.medscape.com/ features/slideshow/ecc2013\#15.

2. Ward E, DeSantis C, Robbins A, Kohler B, Jemal A. Childhood and adolescent cancer statistics, 2014. CA Cancer J Clin. 2014;64(2):83-103.

3. Gurney J, Bondy M. Epidemiology of childhood cancer. In: Principles and practices of pediatric oncology, 5th Ed, Pizzo P, Poplack D. Lippincott Williams and Wilkins, Philadelphia 2006; p.1-13.

4. http://www.cancer.org: Cancer Facts and Figures 2014. Atlanta, Ga: American Cancer Society 2014.

5. Janic D, Dokmanovic L, Jovanovic N, Skoric D, Lazic J. Results of treatment of children with acute lymphoblastic leukemia with a modified BFM protocol. Srp Arh Celok Lek. 2004;132(1):17-22.

6. Stary J, Zimmermann M i sar. Intensive chemotherapy for childhood acute lymphoblastic leukemia: results of the randomized intercontinental trial ALL IC-BFM 2002. J Clin Oncol. 2014;32(3):174-84.

7. Vassal G, Fitzgerald E i sar. Challenges for children and adolescents with cancer in Europe: The SIOP-Europe agenda. Pediatr Blood Cancer. 2014;61(9):1551-7.

8. Berger AH, Knudson AG, Pandolfi PP. A continuum model for tumour suppression. Nature. 2011;476(7359):163-9.

9. Kustanovich AM, Savitskaja TV, Bydanov OI Belevtsev MV, Potapnev MP. Aberrant expression of tumor suppres- 
sor genes and their association with chimeric oncogenes in pediatric acute lymphoblastic leukemia. Leuk Res 2005; 29:1271-1276.

10. Lawrence MS, Stojanov P i sar. Mutational heterogeneity in cancer and the search for new cancer-associated genes. Nature. 2013;499(7457):214-8.

11. Xavier A, Taub J. Acute leukemia in children with Down syndrome. Haematologica 2010;95:1043-1045.

12. Jones LK, Saha V. Philadelphia positive acute lymphoblastic leukaemia of childhood. Br J Haematol 2005; 130:489500.

13. Schultz KR, Carroll A i sar. Long-term follow-up of imatinib in pediatric Philadelphia chromosome-positive acute lymphoblastic leukemia: Children's Oncology Group study AALL0031. Leukemia. 2014;28(7):1467-71.

14. Ford AM, Bennett CA i sar. Fetal origins of the TEL/ AML1 fusion gene in identical twins with leukemia. Proc Natl Acad Sci USA 1998; 95:4584-4588.

15. http://www.encca.eu/

16. DeBaradinis, R. Lum JJ, Hatzivassiliou G, Thompson CB. The biology of cancer: metabolic reprogramming fuels cell growth and proliferation. Cell Metabolism. 2008. 7(1):1120.

17. Hu H, Deng C i sar. Proteomics revisits the cancer metabolome. Expert Rev Proteomics. 2011;8(4):505-33.

18. http://www.cancer.net/cancer-types/childhood-cancer/ symptoms-and-signs

19. Tosato F, Bucciol G i sar. Lymphocytes subsets reference values in childhood. Cytometry A. 2014; doi: 10.1002/cyto.a.22520. [Epub ahead of print].

20. Krstovski N, Tosic N i sar. Incidence of FLT3 and nucleophosmin gene mutations in childhood acute myeloid leukemia: Serbian experience and the review of the literature. Med Oncol. 2010;27(3):640-5.

21. Lazic J, Tosic $\mathrm{N}$ i sar. Clinical features of the most common fusion genes in childhood acute lymphoblastic leukemia. Med Oncol. 2010;27(2):449-53.

22. Lazić J, Dokmanović L i sar. Immunoglobulin genes and T-cell receptors as molecular markers in children with acute lymphoblastic leukaemia. Srp Arh Celok Lek. 2009;137(7-8):384-90.

23. Kotur N, Stankovic B i sar. 6-mercaptopurine influences TPMT gene transcription in a TPMT gene promoter variable number of tandem repeats-dependent manner. Pharmacogenomics. 2012;13(3):283-95.

24. Pearce MS1, Salotti JA i sar. Radiation exposure from CT scans in childhood and subsequent risk of leukaemia and brain tumours: a retrospective cohort study. Lancet. 2012;380(9840):499-505.

25. http://www.siop-online.org/

26. http://www.bfm-international.org/

27. Sudhakar A. History of Cancer, Ancient and Modern Treatment Methods. J Cancer Sci Ther. 2009;1(2):1-4.

28. DeVita VT Jr, Chu E. A history of cancer chemotherapy. Cancer Res. 2008;68(21):8643-53.

29. Delaney G, Jacob S, Featherstone C, Barton M. The role of radiotherapy in cancer treatment: estimating optimal utilization from a review of evidence-based clinical guide- lines. Cancer. 2005;104(6):1129-37.

30. Little MT, Storb R. History of haematopoietic stem-cell transplantation. Nat Rev Cancer. 2002;2(3):231-8.

31. Pardoll DM. The blockade of immune checkpoints in cancer immunotherapy. Nature reviews. Cancer 2012;12 (4): 252-64.

32. Rodriguez-Galindo C, Friedrich P, Morrissey L, Frazier L. Global challenges in pediatric oncology. Curr Opin Pediatr. 2013;25(1):3-15.

33. Dickerman JD. The late effects of childhood cancer therapy. Pediatrics. 2007;119(3):554-68.

34. Bizet P, Saias-Magnan J. i saradnici. Sperm cryopreservation before cancer treatment: a 15-year monocentric experience. Reprod Biomed Online. 2012;24(3):321-30.

35. http://www.pancare.eu/en/

36. http://www.doktoriklovnovi.com/index.html

37. http://www.osdrdraganhercog.edu.rs/

38. http://www.nurdor.org/Pocetna.aspx

39. http://www.dynamocamp.org/en/ 